\title{
The relationship between selection for pituitary responsiveness to gonadotrophin releasing hormone in sheep and differences in gonadotrophin subunit mRNAs
}

\author{
J. R. McNeilly ${ }^{1}$, N. P. Evans ${ }^{1 *}$, T. A. Bramley ${ }^{2}$, P. Brown $^{1}$, \\ A. J. Clark ${ }^{1}$ and R. Webb ${ }^{1}$ \\ ${ }^{1} A F R C$ Institute of Animal Physiology and Genetics Research, Edinburgh Research Station, Roslin, \\ Midlothian EH25 9PS, UK; and ${ }^{2}$ Department of Obstetrics and Gynaecology, University of \\ Edinburgh Centre for Reproductive Biology, Edinburgh EH3 9EW, UK
}

\begin{abstract}
Selection of the luteinizing hormone (LH) response to exogenous gonadotrophin-releasing hormone $(\mathrm{GnRH})$ in sheep has resulted in the establishment of two lines (High and Low) with a fivefold difference in pituitary sensitivity to GnRH. The effect of selection on gonadotrophin gene expression in the presence or absence of an exogenous gonadotrophinreleasing hormone (GnRH) challenge in twenty-week-old ram lambs from both lines was examined. Before treatment with either $\mathrm{GnRH}$ or saline, $\mathrm{LH}$ and follicle-stimulating hormone (FSH) concentrations were significantly higher in the High line than in the Low line animals (LH and FSH: $P<0.01$ ). One hour after either $\mathrm{GnRH}$ or saline, all animals were slaughtered. In the absence of a GnRH challenge, there were significantly higher concentrations of all three gonadotrophin subunit mRNAs in the High line compared with the Low line, corresponding to the higher basal concentrations of $\mathrm{LH}$ and FSH. When comparing treatments between the lines, following a $\mathrm{GnRH}$ challenge, $\mathrm{LH} \beta$ subunit mRNA was significantly $(P<0.001)$ higher in both lines than before the $\mathrm{GnRH}$, whereas there was no significant change in either $\alpha$ or FSH $\beta$ subunit mRNA. These results indicate that the differences in basal gonadotrophin secretion are related to differences in gonadotrophin subunit mRNAs with the High line animals having an inherently greater amount of all three gonadotrophin subunit mRNAs. Selection has not altered the differential amounts of gonadotrophin subunit mRNAs, since there is an overall increase in all three gonadotrophin subunits. GnRH appears to preferentially control LH $\beta$ mRNA in both High and Low line animals.
\end{abstract}

\section{Introduction}

Selection of a reproductive trait in the male to improve reproductive efficiency in the female has led to the establishment of two lines of Finn-Dorset sheep with an altered pituitary sensitivity to physiological and pharmacological concentrations of gonadotrophin-releasing hormone $(\mathrm{GnRH})$ (Evans et al., 1991a). The High $(\mathrm{H})$ line ram lambs have a fivefold greater response to a $5 \mu \mathrm{g} \mathrm{GnRH}$ challenge than the Low (L) line. Further details of the selection criterion and the correlated responses have been reported previously (Lee and Land, 1985; Haley et al., 1989).

Studies in intact ram lambs from these lines have demonstrated that, in addition to differences in magnitude of the $\mathrm{LH}$ responses to exogenous $\mathrm{GnRH}$, there are significantly higher peripheral plasma concentrations of luteinizing hormone (LH) and folliclestimulating hormone $(\mathrm{FSH})$ concentrations in the non-stimulated High line (Evans et al., 1991b). In adult ewes, there is a reduced

*Present address: Reproductive Sciences Program, Dept of Physiology, University of Michigan, Ann Arbor, MI 48109-0404, USA.

Received 22 June 1992. though significant difference between lines in the $\mathrm{LH}$ response to exogenous $\mathrm{GnRH}$. This response varies with the stage of the oestrous cycle; the highest $\mathrm{LH}$ concentrations in each line were observed during the follicular phase. In contrast to the ram lambs, no significant differences between lines were seen in peripheral plasma concentrations of $\mathrm{LH}$ or FSH during either the follicular or luteal phases of the oestrous cycle of adult ewes before the $\mathrm{GnRH}$ challenge. However, during the follicular phase of the cycle, LH pulse amplitude was significantly higher in the High $(\mathrm{H})$ line than in the Low (L) line with no change in LH pulse frequency (Evans, 1991). Studies indicate that selection has not led to any gross morphological changes in the pituitary, although there are a significantly greater number of $\mathrm{GnRH}$ receptors and amount of $\mathrm{LH}$ available for release in response to GnRH in pituitary tissue collected from High $(\mathrm{H})$ compared with Low $(\mathrm{L})$ intact lambs (Evans, 1991).

The aim of the present study was to determine whether, in addition to differences in pituitary $\mathrm{GnRH}$ receptor numbers and releasable $\mathrm{LH}$, the selection programme has led to differences between the lines in basal gonadotrophin subunit mRNA 
concentrations, GnRH binding capacity and the response of the gonadotrophin subunit mRNAs to a $\mathrm{GnRH}$ challenge.

\section{Materials and Methods}

\section{Animals}

Forty ram lambs were selected at birth from the two selection lines (High $(\mathrm{H}), n=20$; Low $(\mathrm{L}), n=20$ ). The lambs from each line were matched for age over the five week lambing period to facilitate handling during tissue collection. After lambing indoors, all ewes and lambs were maintained at pasture; the lambs being weaned at 14 weeks. The day before treatment, the lambs were housed under natural daylight with food and water ad libitum.

\section{Treatment and blood sampling}

At 20 weeks of age, the lambs from each line were randomly allocated to either GnRH (GRF: Hoechst AG, Frankfurt) or saline (control) groups. There were therefore four groups: $\mathrm{H}$ GnRH, $n=10 ; \mathrm{H}$ control, $n=10 ; \mathrm{L} \mathrm{GnRH}, n=10 ; \mathrm{L}$ control, $n=10$.

Blood samples $(5 \mathrm{ml})$ were collected from the jugular vein at $15 \mathrm{~min}$ intervals from $2 \mathrm{~h}$ before to $1 \mathrm{~h}$ after treatment with either a $5 \mu \mathrm{g}$ bolus i.v. injection of $\mathrm{GnRH}$ in $2 \mathrm{ml}$ saline or $2 \mathrm{ml}$ saline alone injected immediately after collection of the blood sample. All samples were collected into heparinized tubes and, after centrifugation at $3000 \mathrm{~g}$ for $20 \mathrm{~min}$, plasma was removed and stored at $-20^{\circ} \mathrm{C}$ until assayed for LH and FSH.

Immediately after collection of the final blood sample, the lambs were slaughtered by an overdose of sodium pentobarbitone (Euthatal: May and Baker, Dagenham). Their pituitary glands were recovered and the posterior pituitary removed. After weighing, the remaining anterior pituitary was chopped into small blocks which were then randomly allocated into three fractions. One fraction was immediately homogenized in $7 \mathrm{~mol}$ guanadinium thiocyanate $\mathrm{l}^{-1}$ for extraction of RNA and the remaining two fractions were stored in liquid nitrogen until determination of $\mathrm{GnRH}$ receptor concentrations.

\section{Measurement of GnRH binding capacity}

One fraction of pituitary tissue was removed from liquid nitrogen and, after thawing on ice, was homogenized using a Polytron homogenizer as described previously (McNeilly et al., 1991). The binding of GnRH was measured as described in detail by Bramley et al. (1985) using the GnRH agonist, buserelin, as tracer and for displacement. The protein content of the homogenate was determined by the method of Lowry et al. (1951) and the GnRH binding capacity expressed as pg GnRH bound $\mathrm{mg}^{-1}$ protein.

\section{Hormone radioimmunoassays}

Plasma LH and FSH were measured by specific doubleantibody radioimmunoassays as described previously (LH: Martenz et al., 1976; FSH: Webb et al., 1985). All samples were assayed for LH, whereas FSH was measured in hourly samples only. In this study, the limits of sensitivity were $0.42 \pm$

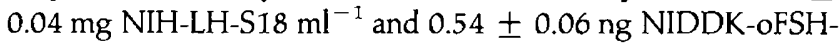
$1 \mathrm{ml}^{-1}$ and the inter- and intra-assay coefficients of variation were 8.3 and $6.8 \%$, for $\mathrm{LH}$ and 10.1 and $6.5 \%$ for $F S H$, respectively.

\section{Measurement of gonadotrophin subunit $m R N A$}

Total cytoplasmic RNA was extracted from individual fresh pituitaries as previously described (McNeilly et al., 1991) and, after measurement of its quality and purity by spectrophotometry at $260: 280 \mathrm{~nm}$, was stored at $-80^{\circ} \mathrm{C}$ until assessment. There were no differences in either the quantity or purity of total RNA between lines or treatments. Samples of total RNA (10-12 $\mu \mathrm{g}$ ) were denatured and electrophoresed through a $1.5 \%$ denaturing gel before transfer and binding onto a nylon membrane (Hybond-N, Amersham International, Amersham). In addition, 4, 1 and $0.1 \mu \mathrm{g}$ of total RNA were denatured with formaldehyde in duplicate before dot-blotting onto nylon membranes. Appropriate RNA transcripts prepared as described previously (McNeilly et al., 1991) and tRNAs were transferred as positive and negative controls for both northern and dot-blot hybridizations.

\section{${ }^{32}$ P-labelled probes}

Plasmids containing specific ovine LH $\beta$ cDNA were donated by W. Miller (North Carolina State University, Raleigh, NC) and F. Esch (Salk Institute for Biological Studies, La Jolla, CA) provided the bovine FSH $\beta$ cDNA and R. Maurer (University of Iowa College of Medicine, Iowa City, IA) the bovine $\alpha$ cDNA. The excised inserts were labelled with $\left[{ }^{32} \mathrm{P}\right] \mathrm{dCTP}$ by random priming to specific activities ranging from $10^{9}$ to $10^{10}$ d.p.m. $\mu \mathrm{g}^{-1}$. All filters were prehybridized separately with each denatured ${ }^{32} \mathrm{P}$-labelled probe, according to Church and Gilbert (1984), then washed and exposed to X-ray film. Efficiency of loading of the gels and membranes was measured by stripping the filters and reprobing with a bovine major histocompatibility complex (MHC) class I cDNA probe (pBoLa: Brown et al., 1988).

The intensity of the bands or dots was measured by scanning densitometry (Shimadzu C9000, Shimadzu Europa $\mathrm{GmbH}$, Duisburg) and the results expressed as the mean densitometer scan units for each treatment group after correcting for loading efficiency using the reprobed membranes.

The specificity of $\left[{ }^{32} \mathrm{P}\right] \mathrm{cDNA}$ probes and the purity of the RNA preparations were assessed by northern blot hybridization as described previously (McNeilly et al., 1991). Northern and dot blot hybridizations were quantified for $\alpha$ and LH $\beta$ mRNA and $\mathrm{FSH} \beta$ gene transcription was assessed by northern blot hybridization only.

\section{Statistical analysis}

All peripheral $\mathrm{LH}$ and FSH data were analysed, after transformation of the data to log scale, by comparing the mean preinjection (basal) values in each of the four treatment groups with the mean post-injection (response) values by ANOVA. In all groups, irrespective of treatment, FSH concentrations at 30 and 
Table 1. Pituitary gonadotrophin-releasing hormone $(\mathrm{GnRH})$ binding capacity and plasma concentrations of luteinizing hormone (LH) and follicle-stimulating hormone (FSH) in lambs selected for high and low responses to GnRH, before and after treatment with either GnRH $(5 \mu \mathrm{g})$ or saline. Plasma gonadotrophin results are expressed as geometric means $\pm \mathrm{SEM}$. GnRH binding capacity is expressed as pg GnRH bound $\mathrm{mg}^{-1}$ protein

\begin{tabular}{|c|c|c|c|c|c|c|}
\hline & & \multicolumn{2}{|c|}{ Mean LH $\left(\mathrm{ng} \mathrm{ml}^{-1} \pm \mathrm{SEM}\right)$} & \multicolumn{2}{|c|}{ Mean FSH $\left(\mathrm{ng} \mathrm{ml}^{-1} \pm \mathrm{SEM}\right)$} & \multirow{2}{*}{$\begin{array}{c}\text { GnRH binding } \\
\text { pg GnRH } \\
\mathrm{mg}^{-1} \text { protein }\end{array}$} \\
\hline & & Pre-treatment & Post-treatment & Pre-treatment & Post-treatment & \\
\hline High line & $\begin{array}{l}\text { Saline } \\
\text { GnRH }\end{array}$ & $\begin{array}{l}2.29 \pm 0.6 \\
3.18 \pm 1.1^{\mathrm{a}}\end{array}$ & $\begin{array}{l}1.09 \pm 0.2 \\
13.6 \pm 4.1^{c}\end{array}$ & $\begin{array}{l}2.23 \pm 0.3^{\mathrm{e}} \\
2.45 \pm 0.5^{\mathrm{eg}}\end{array}$ & $\begin{array}{l}2.19 \pm 0.3 \\
3.60 \pm 0.7^{h}\end{array}$ & $\begin{array}{l}166.9 \pm 29.6 \\
125.2 \pm 25.0\end{array}$ \\
\hline Low line & $\begin{array}{l}\text { Saline } \\
\text { GnRH }\end{array}$ & $\begin{array}{l}1.04 \pm 0.2 \\
2.15 \pm 0.6^{b}\end{array}$ & $\begin{array}{l}1.14 \pm 0.2 \\
4.72 \pm 0.6^{\mathrm{d}}\end{array}$ & $\begin{array}{l}0.91 \pm 0.1^{\mathrm{f}} \\
0.92 \pm 0.3^{\mathrm{f}}\end{array}$ & $\begin{array}{l}0.85 \pm 0.1 \\
1.33 \pm 0.3^{i}\end{array}$ & $\begin{array}{r}136.0 \pm 22.3 \\
98.4 \pm 25.6\end{array}$ \\
\hline
\end{tabular}

Significant differences as indicated by superscript: a versus $c ; b$ versus $d ; c$ versus $d$; e versus $f ; g$ versus $h ; h$ versus $j$ (all at least $P<0.05$ ).

$60 \mathrm{~min}$ after injection were similar and therefore were combined for analysis.

Data obtained from both the GnRH-binding studies and northern and dot blot hybridizations were compared using Student's $t$ test.

\section{Results}

\section{LH and FSH}

Before treatment, mean basal LH concentrations were significantly $(P<0.01)$ greater in the High $(\mathrm{H})$ line than in the Low (L) line animals, irrespective of treatment group (Table 1). Similarly, FSH concentrations were significantly $(P<0.01)$ higher in the High $(\mathrm{H})$ line than in the Low $(\mathrm{L})$ line.

Treatment with GnRH elicited a significant $\mathrm{LH}$ response in both lines when compared with the saline treated animals (GnRH versus saline: High $(\mathrm{H})$ line $P<0.01$; Low (L) line $P<0.05)$. In addition, the High $(\mathrm{H})$ line response to $\mathrm{GnRH}$ was significantly $(P<0.05)$ greater than that observed in the Low (L) line.

Measurement of the FSH response to GnRH indicated significantly higher concentrations in the High $(\mathrm{H})$ line than either within or between the lines (High $(\mathrm{H}) \mathrm{GnRH}$ versus High $(\mathrm{H})$ saline: $P<0.05$; High $(\mathrm{H}) \mathrm{GnRH}$ versus Low (L) GnRH: $P<0.01$; Low (L) GnRH versus Low $(\mathrm{L})$ saline; $P<0.05$ ).

\section{GnRH binding}

Pituitary GnRH binding capacity in the saline treated lambs appeared to be higher in the High $(\mathrm{H})$ line than the Low $(\mathrm{L})$ line, although this was not statistically significant. In contrast, after $\mathrm{GnRH}$ treatment in both lines, there was a reduction in mean pituitary GnRH binding capacity (up to $25 \%$ of saline group values within each line; Table 1 ). However, owing to the large variation within each line, these effects were not significant.

\section{Gonadotrophin subunit mRNA}

In the saline treated groups, there were significant between line differences in all three gonadotrophin subunit mRNA concentrations, with the High $(\mathrm{H})$ line animals having significantly greater quantities of both $\alpha$ and LH $\beta$ subunit mRNA (High $(\mathrm{H})$ versus Low $(\mathrm{L}): \alpha p<0.05$; $\operatorname{LH} \beta p<0.01$ ), while the concentration of FSH $\beta$ mRNA approached statistical significance (Fig. 1).

One hour after treatment with GnRH, there was no change in $\alpha$ subunit mRNA in the Low line $(\mathrm{L})$, whereas the High $(\mathrm{H})$ line lambs showed a decrease (to $80 \%$ of saline treated values). Similarly, there was a reduction in FSH $\beta$ subunit mRNA following $\mathrm{GnRH}$ stimulation in the High $(\mathrm{H})$ line animals; a concentration of $65 \%$ of that of the saline group value was observed. There was no change in FSH $\beta$ subunit mRNA between the $\mathrm{GnRH}$ and saline treated Low (L) line lambs. In contrast, there was an increase in LH $\beta$ mRNA in both High $(\mathrm{H})$ and Low (L) lines following $\mathrm{GnRH}$ stimulation and significant increases of approximately $50 \%(P<0.01)$ and $25 \%(P<0.05)$ were found when compared with the saline treated group in the Low $(\mathrm{L})$ saline and High $(\mathrm{H})$ lines, respectively.

\section{Discussion}

The present study has demonstrated that (i) the significant difference in basal gonadotrophin secretion between the lines is associated with a corresponding difference in the quantity of mRNA for all three gonadotrophin subunits and occurs irrespective of endogenous or exogenous pulses of $\mathrm{GnRH}$, and (ii) following $\mathrm{GnRH}$ stimulation, while there are significant increases in LH and FSH release in both lines, LH $\beta$ mRNA concentrations rise significantly, whereas $\alpha$ and FSH $\beta$ subunit mRNA concentrations do not change. These results confirm our previous observations that selection for response to GnRH has altered both the pulsatile pattern of gonadotrophin release (Evans et al., 1991b) and the sensitivity of the pituitary gland to GnRH (Evans et al., 1991a). They also demonstrate that significantly greater quantities of both LH and FSH are secreted in association with this increased GnRH sensitivity. In addition, the differences in gonadotrophin release between the two lines are related to changes in gonadotrophin subunit mRNAs in the absence of GnRH stimulation.

Previous work demonstrated that there are significant differences in response to $\mathrm{GnRH}$ between the lines from 2 to 20 weeks of age in both intact and castrated ram lambs (Evans et al., 
(a)

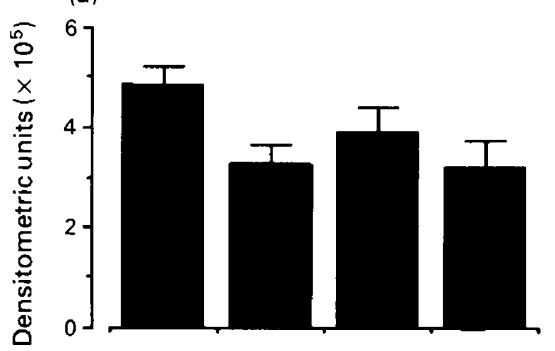

(b)

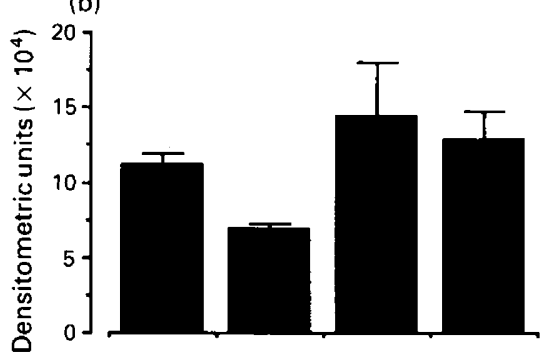

(c)

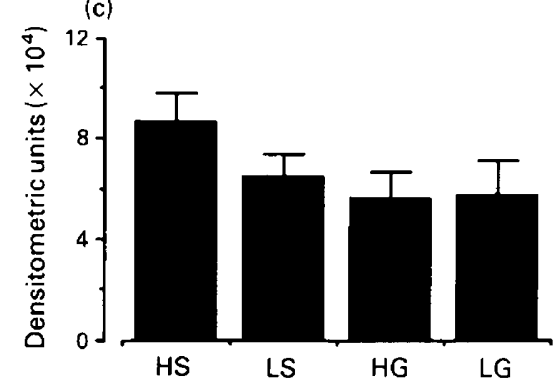

Fig 1. Gonadotrophin subunit mRNA concentrations in pituitary glands from ram lambs in lines selected for High (H) and Low (L) LH responses to $\mathrm{GnRH}$ after treatment with either $\mathrm{GnRH}(5 \mu \mathrm{g})$ or saline. (a) $\alpha$ mRNA, (b) LH $\beta$ mRNA and (c) FSH mRNA. Results are expressed as mean densitometric units \pm SEM. HS and LS are the High and Low saline treated groups; HG and LG are the High and Low GnRH-treated groups. Analysis by Student's $t$ test indicated the following significant differences: $\alpha$ mRNA, HS versus LS, $P<0.05$; LH $\beta$ mRNA, HS versus LS, $P<0.01$; HS versus HG, $P<0.05$; LS versus LG, $P<0.01$.

1991b). This study also suggested that there were differences in basal LH and FSH concentrations between the lines despite the infrequent sampling. No differences in testosterone or oestradiol concentrations were observed between the lines during this period. From these data, it was concluded that the differences in both basal gonadotrophin secretion and response to $\mathrm{GnRH}$ between the lines are not controlled primarily by steroid feedback but presumably are due to inherent differences within the hypothalamo-pituitary gland complex.

Measurement of endogenous LH pulses in young prepubertal ram lambs from both lines showed no differences in pulse amplitude. By determining the $\mathrm{LH}$ response to a wide range of physiological doses of GnRH in these lambs, it has been possible to assess the quantity of $\mathrm{GnRH}$ required in each line to elicit endogenous $\mathrm{LH}$ pulses of similar amplitude indirectly. From this study, it was concluded that endogenous LH pulses in the High $(\mathrm{H})$ line require significantly less $\mathrm{GnRH}$ than the Low (L) line (Evans et al., 1991a) and hence selection appears to have caused differences at the hypothalamus.
However, the present study has shown that there are significant differences in basal LH and FSH secretion between the lines that are related to changes in the concentrations of all three gonadotrophin subunit mRNAs. In the High $(H)$ line, the increase in basal gonadotrophin secretion could be due to either increased efficiency of the gonadotrophes or the recruitment of an increased number of active gonadotrophes. A preliminary immunocytochemical study indicated no differences in the number of gonadotrophes between the lines, although the lack of highly specific antisera made it impossible to determine whether the individual cells were producing LH or FSH (monohormonal) or both $\mathrm{LH}$ and FSH (multihormonal). As there was no difference in $\mathrm{GnRH}$ binding between the lines, the present results suggest that the same number of gonadotrophes were present in both High and Low lines but that each gonadotrophe produces more hormone in the High line.

Selection has caused changes in both LH and FSH mRNA concentrations and release. This would suggest that there is a relationship between $\mathrm{LH}$ and $\mathrm{FSH}$ and that they may be produced from the same cell, as appears to be the case in the rat where the majority of gonadotrophes are multihormonal producing both $\mathrm{LH}$ and FSH with two smaller populations secreting LH and FSH, respectively (Childs et al., 1987, 1990). However, in cows, all gonadotrophes appear to be monohormonal, producing either LH or FSH as demonstrated by immunocytochemistry (Bastings et al., 1991), in which case a similar selection programme might possibly affect the selected gonadotrophin alone. It is still not known in the sheep whether $\mathrm{LH}$ and FSH are produced in the same or different cells.

The mechanism by which basal gonadotrophin secretion is regulated remains unclear. In sheep treated long term with a $\mathrm{GnRH}$ agonist and which were unresponsive to GnRH pulses, it was demonstrated that basal gonadotrophin secretion is not primarily controlled by $\mathrm{GnRH}$ pulses and hence may not be dependent on GnRH receptor binding ability and the GnRH receptor-effector system (McNeilly ef al., 1991). It appears that the High $(\mathrm{H})$ line animals have inherently higher concentrations of all three gonadotrophin subunit mRNAs leading to increased peripheral gonadotrophin concentrations. This suggests that selection has not altered differential regulation by $\mathrm{GnRH}$. However, the increase in gonadotrophin subunit mRNA concentrations in the High line could be related to an increase in the basal non-pulsatile secretion of GnRH, although direct measurement of $\mathrm{GnRH}$ has not been undertaken in these lines. There are no studies in vivo on the relationship between basal non-pulsatile secretion of $\mathrm{GnRH}$, gonadotrophin gene expression and the consequent basal value of gonadotrophin secretion. However, it has been demonstrated that infusion of constant physiological concentrations of $\mathrm{GnRH}$ was ineffective in stimulating $\mathrm{LH} \beta$ or $\mathrm{FSH} \beta$ transcription although $\alpha$-subunit mRNA did increase (Haisenleder et al., 1991). However, the same quantity of $\mathrm{GnRH}$ administered in a pulsatile manner stimulated a maximum rise in $\alpha$-subunit mRNA and a smaller increase in LH $\beta$ (Dalkin et al., 1989). In these lines, there is no difference in either LH pulse frequency or gene transcription between the subunits within the lines as would have been expected if selection for GnRH sensitivity had altered the differential regulation of gonadotrophin gene expression. Thus selection for a high LH response to GnRH has resulted in an overall increase in expression of all three gonadotrophin subunit genes. 
In lambs treated with $\mathrm{GnRH}$, the decrease in $\mathrm{GnRH}$ receptor numbers in both lines indicates receptor occupancy following a pharmacological GnRH challenge (Clayton, 1989). At one hour after treatment, circulating LH in both lines has fallen to $50 \%$ of the maximum response. It was anticipated that $\mathrm{LH}$ synthesis would be occurring at this time in both lines, although the time of initiation of LH synthesis following GnRH stimulation and subsequent LH release in the sheep is unclear. However, $1 \mathrm{~h}$ after $\mathrm{G} n \mathrm{RH}$ administration, $\mathrm{LH} \beta$ subunit mRNA concentration had increased, whereas there was a decrease in the quantity of both $\alpha$ and FSH $\beta$ subunit mRNAs. This suggests, in agreement with other studies, that $\mathrm{GnRH}$ preferentially controls $\mathrm{LH} \beta$ subunit gene expression (Lalloz et al., 1988; Papavasiliou et al., 1986). It is quite possible that the lack of an effect of $\mathrm{GnRH}$ on either $\alpha$ subunit or FSH $\beta$ subunit mRNA is due to an inappropriate sampling schedule and thus requires further studies. However, the relationship between GnRH and $\alpha$ and FSH $\beta$ subunit gene expression has been investigated by Mercer et al. (1989) using the hypothalamo-pituitary disconnected (HPD) sheep model to demonstrate that the absence of $\mathrm{GnRH}$ pulses leads to a substantial reduction in both subunit mRNAs.

In conclusion, selection for sensitivity to GnRH has resulted in animals that have inherently higher basal concentrations of gonadotrophin subunit mRNA and respond more efficiently to $\mathrm{GnRH}$ stimulation. This has led to greater and more readily available stores of LH. The mechanisms by which this greater efficiency is achieved are not clear. It must be emphasized that, despite these dramatic changes in the control of gonadotrophin secretion, no gross changes in reproductive efficiency have been observed. Transient alterations in ovulation rate during the first two breeding cycles are the main physiologically significant differences between the lines.

We are indebted to M. Ritchie, S. B. Wilson, W. R. Ritchie and M. Thompson and the staff at Blythbank Farm for technical assistance and care of the animals and to A. J. Springbett for statistical analyses. Gifts of the gonadotrophin cDNA probes from F. Esch, W. Miller, I. H. Nilson and R. A. Maurer are gratefully acknowledged as are the hormones and antisera for the radioimmunoassays from the NIDDK and the National Hormone and Pituitary Program (University of Maryland School of Medicine). N. P. Evans was in receipt of an AFRC postgraduate grant.

\section{References}

Bastings E, Beckers A, Reznik M and Beckers J-F (1991) Immunocytochemical evidence for the production of luteinizing hormone and follicle stimulating hormone in separate cells in the bovine Biology of Reproduction 45 788-796

Bramley TA, Menzies GS and Baird DT (1985) Specific binding of gonadotrophinreleasing hormone and an agonist to human corpus luteum homogenates: characterization, properties and luteal phase levels Journal of Clinical Endocrinology and Metabolism 61 834-841

Brown P, Spooner RL and Clark AJ (1988) Cloning and characterization of a BoLA class 1 cDNA clone Immunogenetics 29 58-60
Childs GV, Unabia G, Tibolt R and Lloyd JM (1987) Cytological factors that support non-parallel secretion of LH and FSH during the estrous cycle Endocrinology 121 1546-1558

Childs GV, Unabia G, Wierman ME, Shupnik MA and Chin WW (1990) Castration induces time-dependent changes in the follicle-stimulating hormone $\beta$-subunit messenger RNA ribonucleic acid-containing gonadotroph cell population Endocrinology 126 2205-2213

Church GM and Gilbert W (1984) Genomic sequencing Proceedings of the National Academy of Sciences USA 81 1991-1995

Clayton RN (1989) Gonadotrophin-releasing hormone: its actions and receptors Journal of Endocrinology 120 11-19

Dalkin AC, Haisenleder DJ, Ortolano GA, Ellis TS and Marshall JC (1989) The frequency of gonadotropin-releasing-hormone stimulation differentially regulates gonadotropin subunit messenger ribonucleic acid expression Endocrinology 125 917-924

Evans NP (1991) The Regulation of Gonadotrophin Secretion Following Divergent Selection for Pituitary Responsiveness to GnRH. PhD Thesis, University of Edinburgh

Evans NP, McNeilly JR, Springbett AJ and Webb R (1991a) Alterations in pituitary gland sensitivity in ram lambs to physiological doses of gonadotrophinreleasing hormone $(\mathrm{GnRH})$, after divergent selection based on the luteinizing hormone response to a pharmacological $\mathrm{GnRH}$ challenge Journal of Reproduction and Fertility 93 559-567

Evans NP, Land RB, McNeilly JR and Webb R (1991b) Role of gonadal negative feedback on the gonadotrophin responses to gonadotrophin releasing hormone $(\mathrm{GnRH})$ in ram lambs from two lines of sheep selected for their luteinizing hormone response to GnRH Journal of Reproduction and Fertility 93 549-558

Haisenleder DJ, Dalkin AC, Ortolano GA, Marshall JC and Shupnik MA (1991) Pulsatile gonadotropin-releasing hormone stimulus required to increase transcription of the gonadotropin subunit genes: evidence for differential regulation of transcription by pulse frequency in vivo Endocrinology 128 509-517

Haley CS, Lee GJ, Fordyce M, Baxter G, Land RB and Webb R (1989) Study of the $\mathrm{LH}$ response to $\mathrm{GnRH}$ in the young male as a criterion of genetic merit for reproduction Journal of Reproduction and Fertility 86 119-133

Lalloz MRA, Detta A and Clayton RN (1988) Gonadotrophin releasing hormone is required for enhancing luteinizing hormone suburit gene expression in vivo Endocrinology 122 1681-1688

Lee GJ and Land RB (1985) Testis size and LH response to LH-RH as male criteria of female reproductive performance. In Reproduction in Sheep pp 331-341 Eds RB Land and DW Robinson. Butterworths, London

Lowry OH, Rosebrough NJ, Farr AL and Randall RJ (1951) Protein measurement with the Folin phenol reagent Journal of Biological Chemistry 193 265-275

McNeilly JR, Brown P, Clark AJ and McNeilly AS (1991) Gonadotrophinreleasing hormone modulation of gonadotrophins in the ewe: evidence for differential effects on gene expression and hormone secretion Journal of Molecular Endocrinology 7 35-43

Martensz NA, Baird DT, Scaramuzzi RT and Van Look PFA (1976) Androstenedione and the control of luteinizing hormone in the ewe Journal of Endocrinology 69 227-237

Mercer JE, Clements JA, Funder JW and Clarke IJ (1989) Regulation of folliclestimulating hormone $\beta$ and common $\alpha$-subunit messenger ribonucleic acid by gonadotropin-releasing hormone and estrogen in the sheep pituitary Neuroendocrinology 50 321-326

Papavasiliou SS, Zmeili S, Khoury S, Landefeld TD, Chin WW and Marshall JC (1986) GnRH differentially regulates expression of the genes for $\mathrm{LH} \alpha$-and $\beta$-subunits in male rats. Proceedings of the National Academy of Sciences USA 83 4026-4029

Webb R, Baxter G, Preece RD, Land RB and Springbett AJ (1985) Control of gonadotrophin release in Scottish blackface and Finnish Landrace ewes during seasonal anoestrus Journal of Reproduction and Fertility 73 369-378 